\title{
Margaret McCartney: Bruce Keogh's letter to junior doctors: the importance of independence
}

\author{
Margaret McCartney general practitioner, Glasgow
}

Independence is so vital a quality, so cherished, that wars have been repeatedly fought over it. In medicine, independence is about ethics. Having independence reflects individual autonomy and is an inherent safety device. When we make up our minds independently we reduce bias, particularly "groupthink." We protect ourselves against acting in others' interests rather than those of the patient or person we should be focused on. We ensure that whistleblowers can act.

When independence has been threatened, we're right to be alarmed. Conflicts in medicine are everywhere, and we can't get rid of them all. Rather, we have to protect ourselves from undue, conflicting influence by remaining as independent as possible.

The Quality and Outcomes Framework created low value box ticking, for GPs in particular, rather than concentrating on what patients need. It's been castigated for de-professionalising doctors through political micromanagement. ${ }^{1}$ It's created systemic problems: we look at the computer screen rather than at the patient, because ticking boxes pleases the contract and our wages, though not necessarily the patient. Paying GPs to diagnose more dementia was a dreadful, easily avoidable conflict. $^{2}$

Healthcare professionals work for Atos, a company that has done fitness to work assessments for the government's Department for Work and Pensions. When one doctor was pressured to change a medical report unjustifiably, he resigned and blew the whistle-much respect to him. ${ }^{3}$

Doctors are trusted overwhelmingly more than politicians. ${ }^{4}$ Doctors who receive information or advice from colleagues, especially senior colleagues, may be inclined to trust it more or to question it less. Jeremy Hunt, the health secretary, has written to junior doctors regarding his dispute with the BMA. Junior doctors know who is writing, and they made their own judgments about how to interpret it.

Bruce Keogh, medical director of NHS England, also wrote to junior doctors recently, but before his letter was sent it was changed, after communication with Department of Health employees. They wanted it to be more "hard edged" and to make reference to the need for emergency services in the event of a terrorist attack. ${ }^{5}$ I'm sure that junior doctors, along with the rest of us, know our moral and ethical obligations if disaster does strike.

Of course, the Department of Health and NHS England need to be in close contact. But surely rigid lines should also be drawn so that we know who speaks for whom. Bizarrely, in its defence, the department has stated that "it was absolutely right that ministers insisted on Bruce Keogh giving his independent view." Although Keogh's view may have just happened to coincide with the department's view, we need to be assured that these views were arrived at entirely independently.

Competing interests: I have read and understood BMJ policy on declaration of interests and declare the following interests: I'm an NHS GP partner, with income partly dependent on Quality and Outcomes Framework points. I've written two books and earn from broadcast and written freelance journalism. I'm an unpaid patron of Healthwatch. I make a monthly donation to Keep Our NHS Public. I'm a member of Medact. I'm occasionally paid for time, travel, and accommodation to give talks or have locum fees paid to allow me to give talks but never for any drug or public relations company. I was elected to the national council of the Royal College of General Practitioners in 2013 and am chair of its standing group on overdiagnosis. I have invested a small amount of money in a social enterprise, Who Made Your Pants?

Provenance and peer review: Commissioned; not externally peer reviewed.

Follow Margaret on Twitter, @mgtmccartney

Gillam S, Siriwardena N. The Quality and Outcomes Framework: QOF-transforming general practice. CRC Press, 2010.

Brunet $\mathrm{M}$. Target diagnosis rates in primary care are misleading and unethical. BMJ 2014;349:g7235.

3 Gentleman A. Why I blew the whistle on the Atos fit-for-work test. Guardian 2013 Jul 31 www.theguardian.com/society/2013/jul/31/atos-fitness-work-test-greg-wood.

4 Ipsos MORI. Trust in professions. 5 Jan 2015. www.ipsos-mori.com/researchpublications researcharchive/15/Trust-in-Professions.aspx.

5 Cooper C. Junior doctors: Whitehall edited letter from "independent" medic to build "hard-edged" case against strike. Independent $2016 \mathrm{Jan} 7$. http://static.independent.co. uk/s3fs-public/thumbnails/image/2016/01/07/20/how-the-text-changed.jpg; http://ind.pn/ $1 \mathrm{kQIhdE}$. 
